\title{
Type and evolution of carbonate platforms in Jixian Period Mesoproterozoic: southwestern margin of Ordos Basin
}

\author{
Youzhi Chen ${ }^{1,2,3} \cdot$ Xiaofei $\mathrm{Fu}^{3} \cdot$ Ancheng Xiao ${ }^{1,2} \cdot$ Long Yu ${ }^{1,2} \cdot$ Yong Tang ${ }^{4} \cdot$ \\ Liguang Mao ${ }^{1,2}$
}

Received: 25 December 2014/Accepted: 20 November 2015/Published online: 7 December 2015

(C) The Author(s) 2015. This article is published with open access at Springerlink.com

\begin{abstract}
The Ordos block experienced extension in the Mesoproterozoic, during which the Longshan-Kuanping and Haiyuan rifts developed on its southwest margin. The Jixian Group (1.6-1.4 Ga) is mainly exposed on the rimmed and ramp-type platforms at the Qishan County, southwest of the Ordos block. The deposition associated with the rimmed platform margin consists of platform facies, platform edge facies, and slope facies, which are characterized by small tidal creeks, mud cracks and scour troughs, rockfalls, respectively. The ramp-type platform is dominated by platform edge facies, shelf facies and slope facies and featured by intraclastic dolostones, tempestites and debris flow sediments respectively. The syndepositional normal faults were well developed at the early stage of the rifting. Fault-related cracks and folds present in the adjacent strata. The uplift of the footwall rimmed the platform. The drag structures determine the local sedimentary environment. In the final stage of the rifting, the fault movement stopped. The surrounding rocks were undeformed. The slope became less steep, resulting in the formation of ramp-type platform. The study area in the Jixian period, Mesoproterozoic is located at a palaeo-
\end{abstract}

Youzhi Chen

chenziyikangong@163.com

1 Department of Earth Sciences, Zhejiang University, Hangzhou 310027, Zhejiang, China

2 Research Center for Structures in Oil and Gas Bearing Basins, Ministry of Education, Hangzhou 310027, Zhejiang, China

3 College of Earth Sciences, Northeast Petroleum University, Daqing 163318, China

4 Hubei Cooperative Innovation Center of Unconventional Oil and Gas, Yangtze University, Wuhan 430100, Hubei, China continental margin, which has already shown good petroleum prospectivity. A clear study on the type of carbonate platforms and the evolution of the platforms can help reduce exploration risks by improve the understanding of the presence of the source rocks.

Keywords Carbonate platform $\cdot$ Fault $\cdot$ Sedimentary facies $\cdot$ Mesoproterozoic $\cdot$ Ordos

\section{Introduction}

The Ordos block is located in the southwest of the North China plate and has undergone multiple tectonic settings. The Weihe rift was developed at the southern margin of Ordos block in the late Mesozoic-Cenozoic. The ca. 1.6-1.4 Ga Middle Proterozoic Jixian Group, which is exposed at the edge of the block and composed mainly of dolostones and silica rocks, presents as a good chance to study the type of the carbonate platforms and the transition between different types. The Ordos block was adjacent to the Qin-Qi Sea to the southwest during the Jixian Period. The sedimentary environment of the Qin-Qi Sea is shallow marine (Yan et al. 1989) or tidal flat of marginal marine (Deng et al. 2009). However, the spatial distribution of sedimentary facies remains poorly understood.

This paper aims to provide clear understanding of the type and the depostional environments of carbonate platforms, as well as their relations with the syn-depositional normal faults. This study can play significant role in understanding the spatial distribution of the source rocks and thus reducing risks in exploration activities in the Ordos basin. Besides, it may also be taken as a good reference for the study of carbonate platforms elsewhere in the world. 


\section{Geological setting}

The Ordos block was formed at the early Proterozoic era (Bai 1993), after which it underwent extension stage, and abundant failed rifts and strata of shallow and littoral facies aged ca. 1.8-1.6 Ga were reported on the periphery of the Ordos block (Zhang 1983; Sun et al. 1985; Tang et al. 1993; Zhao and Zhou 2009; Peng 2010). After a transient uplift (Wu 2002), the southwestern margin of Ordos block were affected by Longshan-Kuanping and Haiyuan rift in the Mesoproterozoic (Huo and Zheng 1988; Yan et al. 1989; Di 2003; Li et al. 2006; Dong et al. 2014). The carbonate platforms were developed in these rift events.

The Jixian Group in or around Ordos block exposes mainly in Luonan-Huayin county, Long county, Qishan county, Helan mountain and Qinglong mountain. The typical stratigraphic section in Luonan county is divided into four Formations from bottom to top: Longjiayuan, Xunjiansi, Duguan, Fengjiawan (Yan et al. 1989). Revealed by drilling data and outcrops observation (Yan et al. 1989; Deng et al. 2009), the thickness of Jixian Group increases from the block center to margin and the western margin is thicker than the eastern margin. Compared with the typical section, the Fengjiawan Formation is absent in the study area, and the thicknesses of Longjiayuan Formation and Xunjiansi Formation are greater (Figs. 1, 2).

A lot of asphalt in algae dolomite of Jixian Group was discovered in Chongxin county (Gansu Province) in the southwest of Ordos block, and was believed to stem from the algae dolomite ( $\mathrm{Li}$ et al. 2011). This place has similar sedimentary environment and tectonic setting compared with our study area in Jixian Period.

\section{Methodology}

The study area is situated in the southwestern margin of the Ordos block, and is about $30 \mathrm{~km}$ away from the Qinling block (Fig. 1). More than 1000-m thick Jixian Group was deposited in the study area. A fieldtrip was conducted to observe the general sedimentary facies and structural features of the Jixian Group, as well as to take samples for further study. The microscope analysis was implemented for samples taken from the field to determine the rock microstructures.

Mesoproterozoic Jixian Group is a monoclinal structure dipping towards NW, unconformably overlied by the Cambrian rocks. The observation line started at point 1, which is near the boundary of Jixian Group, and extends

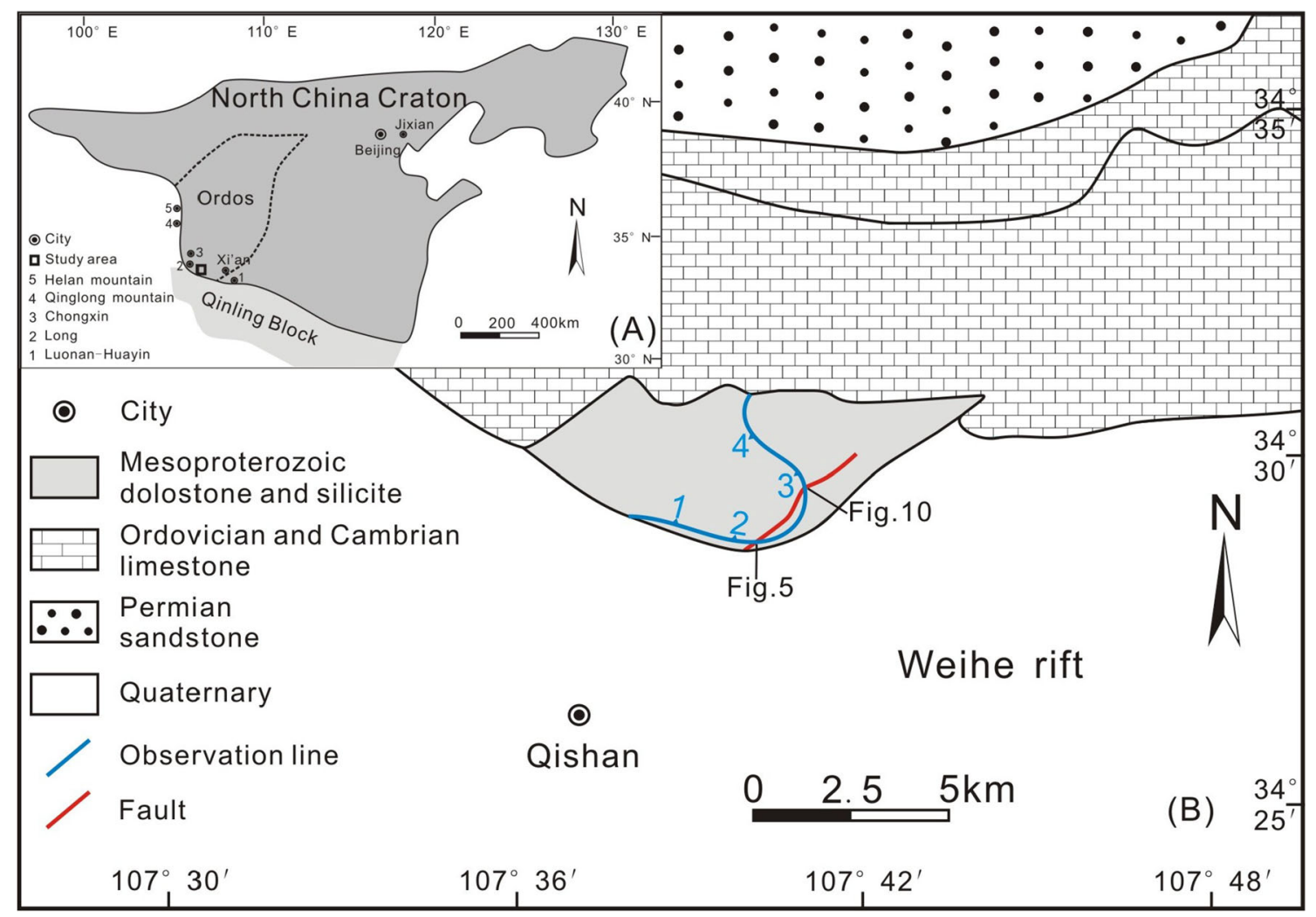

Fig. 1 a Location map of Ordos in North China Craton (study area is in southwest margin of Ordos). b Simplified geological map of study area (modified from GBSP 1966), with observation line in blue 
Fig. 2 Lithological histograms of Jixian System in Qishan, Luonan and Jixian (modified from Di 2003; Gao et al. 2008)

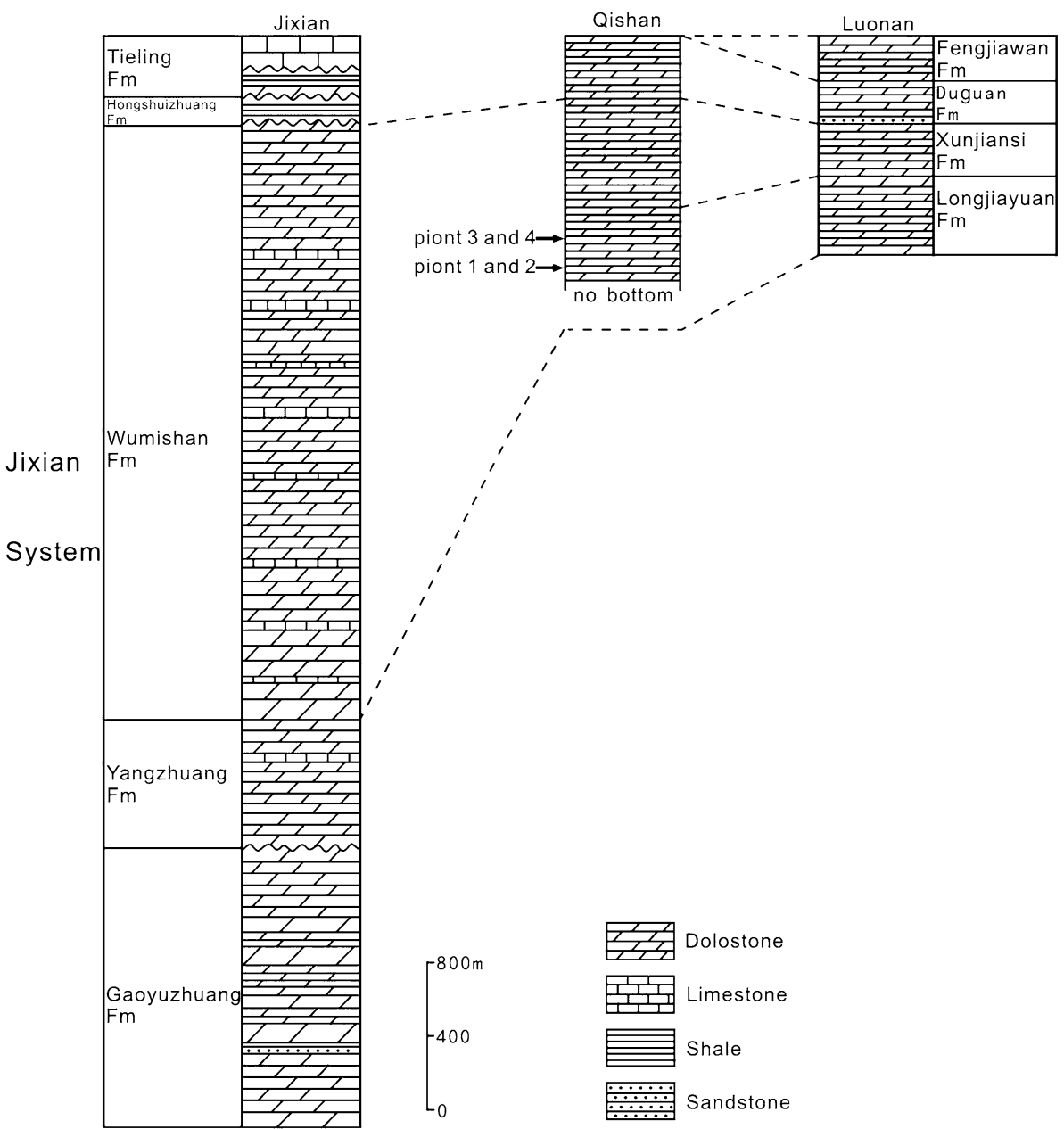

along SEE to point 2, where the rockfalls appeared. Then it goes along NNE to point 3, where debris flow occurs, at which it turns to NW, ending at point 4 (Fig. 1). The points 1 and 2 are topographically lower than 3 and 4, with an altitude difference of $150 \mathrm{~m}$. A syn-depositional fault of about $3.5 \mathrm{~km}$ in length is identified in the study area, trending NE-SW, dipping to SE with an angle of $64^{\circ}-80^{\circ}$. It separates carbonate platforms from gravity flow deposits.

\section{Sedimentary facies and fault activity}

The rimmed shelf edge is in high elevation due to the development of the organic reefs. It has a steep slope in higher-energy depositional environment. The ramp-type platform was located in deep water with gentle inclination. The carbonate sedimentary facies in this study is determined based on the criterion of Wilson (1975). The sedimentary microfacies of rimmed shelves edge include restricted platform lagoon, platform-margin reef, and talus breccias on slope. While the ramp platform margin includes tidal-flat, ooid-pellet shoal, open marine shelf and gravity flows on slope (Read 1985).

The four stratigraphic columns in Fig. 3 correspond to 1, 2, 3, 4 observation points in Fig. 1. Their sedimentary structure will be addressed in the following.

\section{Sedimentary facies pattern of rimmed platform margin and fault activity}

\section{Platform facies}

The platforms, behind rimmed shelf margin reef, are usually in the intertidal-subtidal zone, showing tidal creeks. Small tidal creek often suggests low lateral migration speed of the creek itself, but strong vertical erosion. The geometry of every single creek is concave downwards. The small tidal creeks were formed in alternate erosion and deposition filling process, and the creeks in different ages are overlapping each other (Scholle et al. 1983; Zhang et al. 1984). 


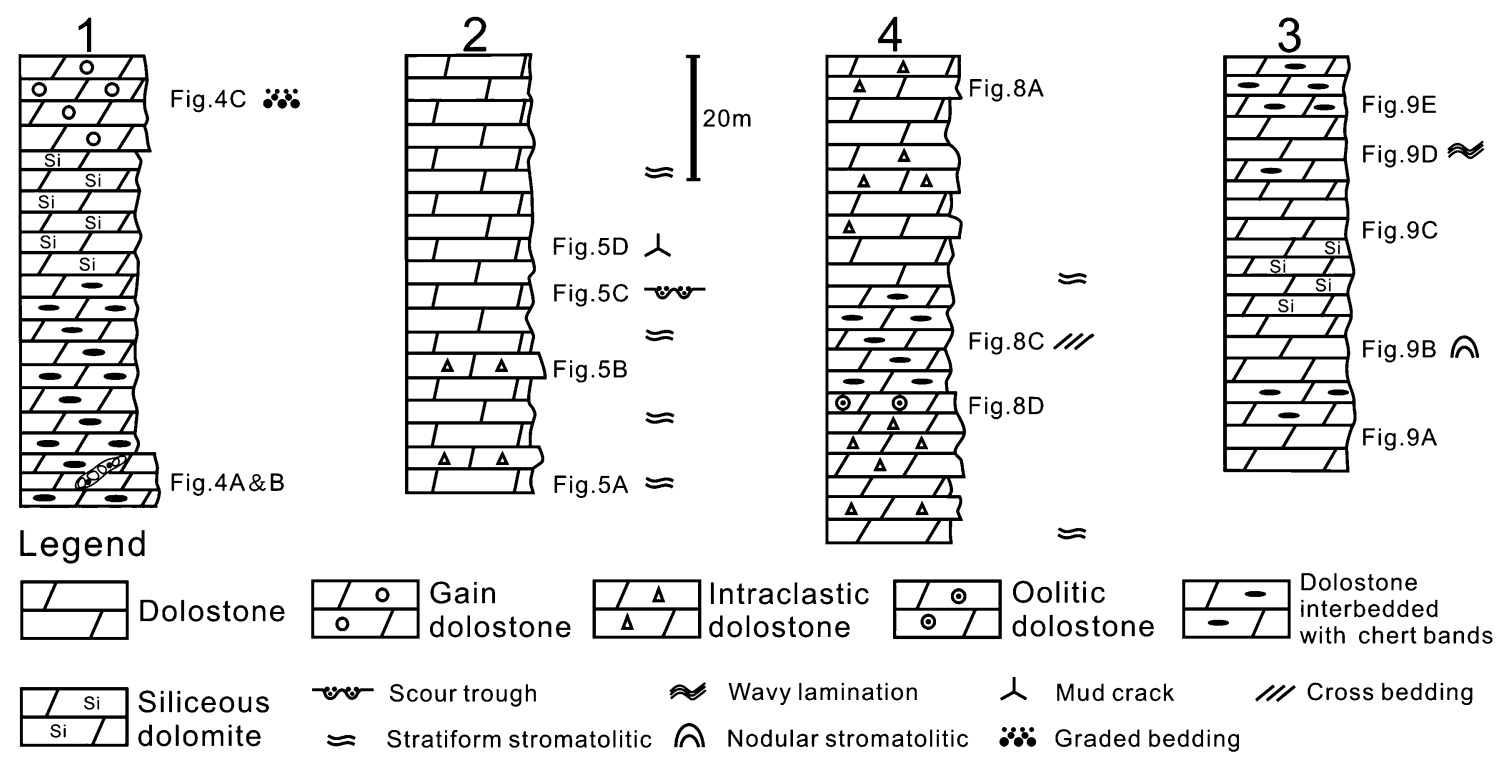

Fig. 3 Stratigraphic columns of the four observation points (locations see Fig. 1)
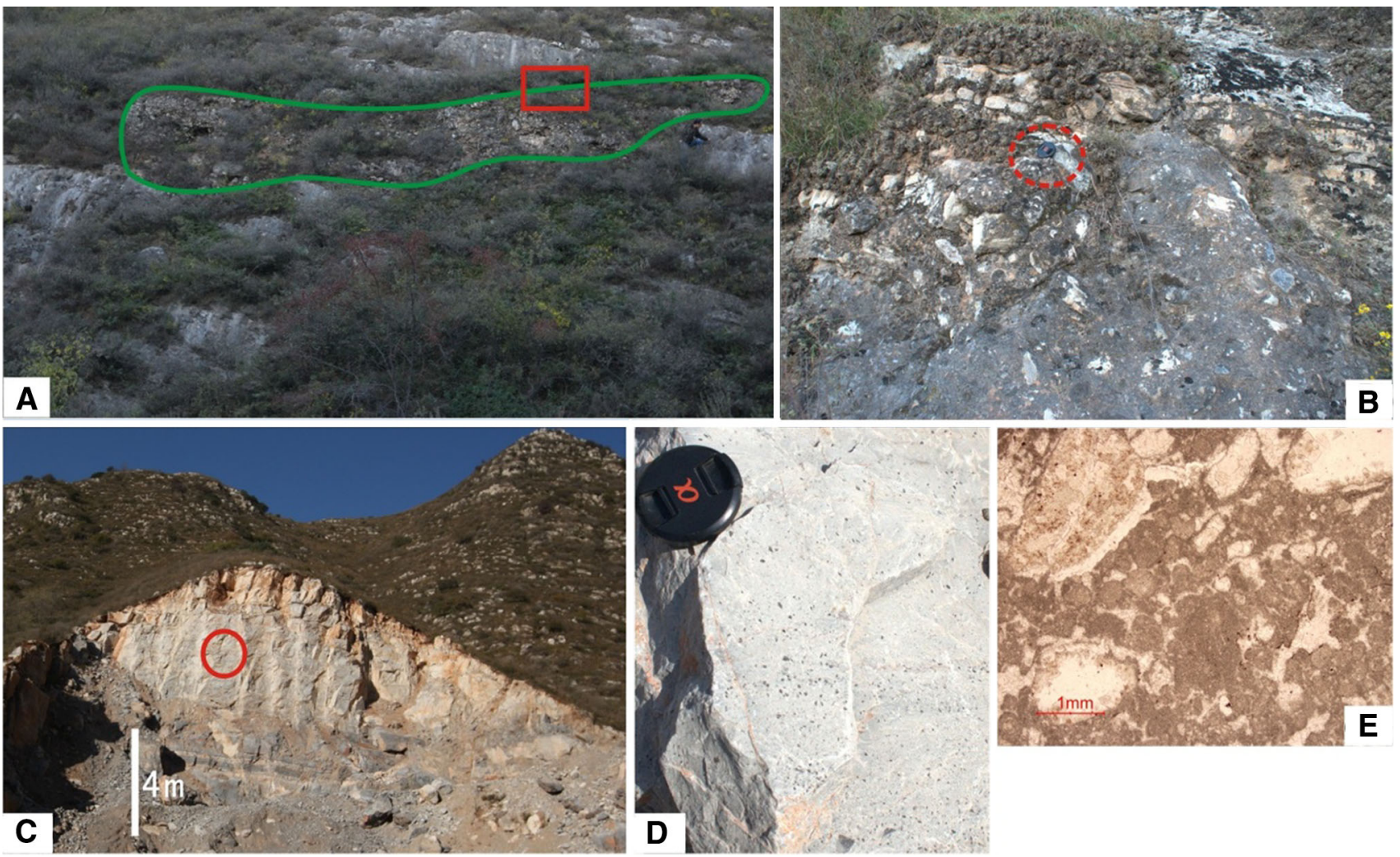

Fig. 4 a Photograph showing the boundary of tidal creeks. b Amplified photograph of the boundary, highlighted in red retangular in a (each phase of tidal creek in concave shape). c Medium-thick

Tidal creeks presents at the bottom of observation point 1 (Fig. 3), around $8 \mathrm{~m}$ in height. It is surrounded by thin dolostones interbedded with chert bands. The shape of the sedimentary bodies is irregular lenticular (Fig. 4a). bedded grain dolomites near the red circle in $\mathbf{b}$. $\mathbf{d}$ Graded structure in grain dolomites in $\mathbf{c}$. e Photomicrograph of $\mathbf{d}$

Each tidal creek has a rough downwards-concave boundary, and the deposits borne in the creek are composed of the conglomerate at the bottom, collapse breccia at the creek margin and the uniform dolomite surrounded 
(Fig. 4b). The small tidal creeks have relative poor lateral continuity (Zhang et al. 1984). Sedimentary units of different ages overlap each other and form lens-shape. The widths of tidal creeks decrease from bottom to top. The gravels are composed of dolostone and siliceous rocks, with $0.5-70 \mathrm{~cm}$ ( $20 \mathrm{~cm}$ mean value) in size, and spherical to sub-angular in shape. These gravels have groundmass of small amount of mud and sand.

The grain dolomite is easily recognized within the platforms, where the hydrodynamic energy is moderate to low. At the upper column of observation point 1 , a about 14-m thick, medium-bedded grain dolomite layer (Fig. 4c) presents containing a set of black graded debris sediments (Fig. 4d). Under the microscope, the debris rocks are mainly made up of dolostone and silicalite, with grain size of $0.2-2.5 \mathrm{~mm}$ ( $0.3 \mathrm{~mm}$ on average) (Fig. $4 \mathrm{e}$ ).

\section{Platform edge facies}

The platform edge shoals are adjacent to ramps and approximately at the mean sea level. As shown by point 2 in Fig. 3, grey black and grey white thin-bedded dolostones with stratiform algaes present alternately (Fig. 5a). Algae is diagnostic for aquatic environment, and the stratifrom algae in the shallow water is mostly found in supratidal zone (Hoffman 1976), which has medium flow intensity. A number of $0.1-2 \mathrm{~cm}$ angular or subangular breccias were seen in the stromatolitic dolostones (Fig. 5b). They are probably formed by the flow entrenchemnt on the unconsolidated formation. The sedimentary structures are scour troughs and mud cracks (Fig. 5c, d), indicating that the beds was exposed in the air during the process of deposition. All these prove that the sedimentary sub-environment of the point 2 is the rimmed platform edge shallow.

\section{Slope facies and fault activity}

Rockfalls, slides and sediment gravity flows are well developed on continental slope (Varnes 1978). Slides can induce brittle and plastic deformation (Varnes 1978; Scholle et al. 1983). In southeast of point 2 (Fig. 1), the slope sediments were divided into two parts by the normal fault. The upper part of the slope developed sliding
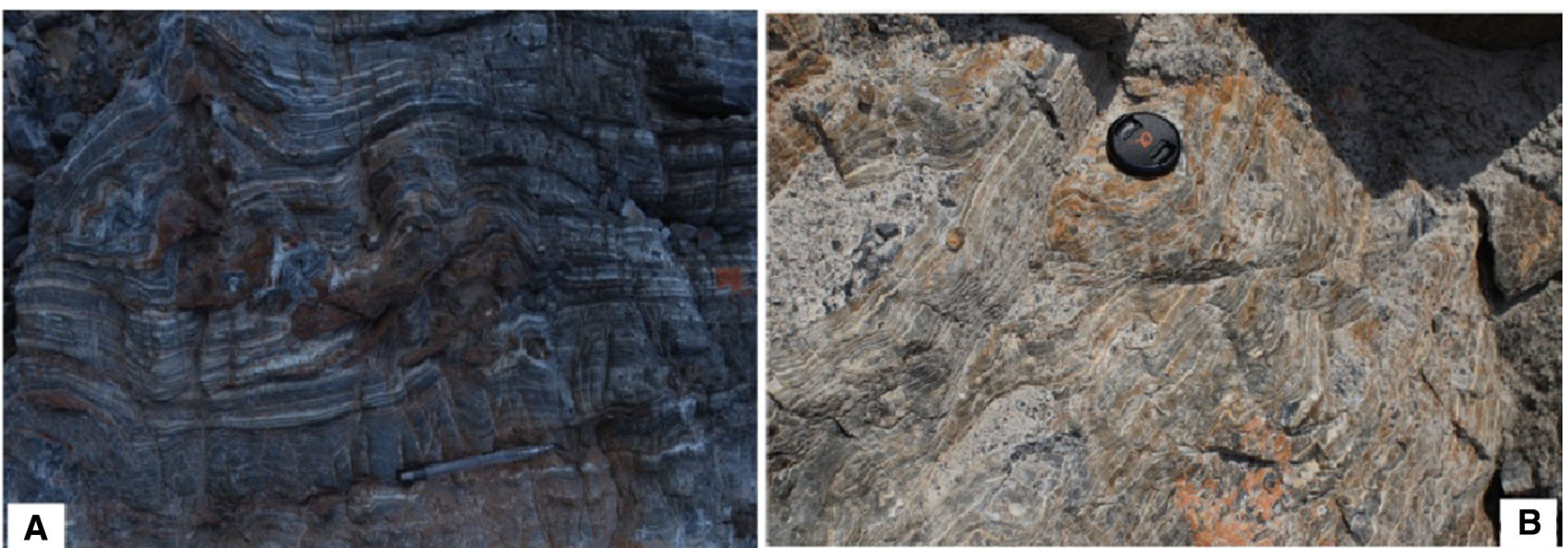

\section{A}
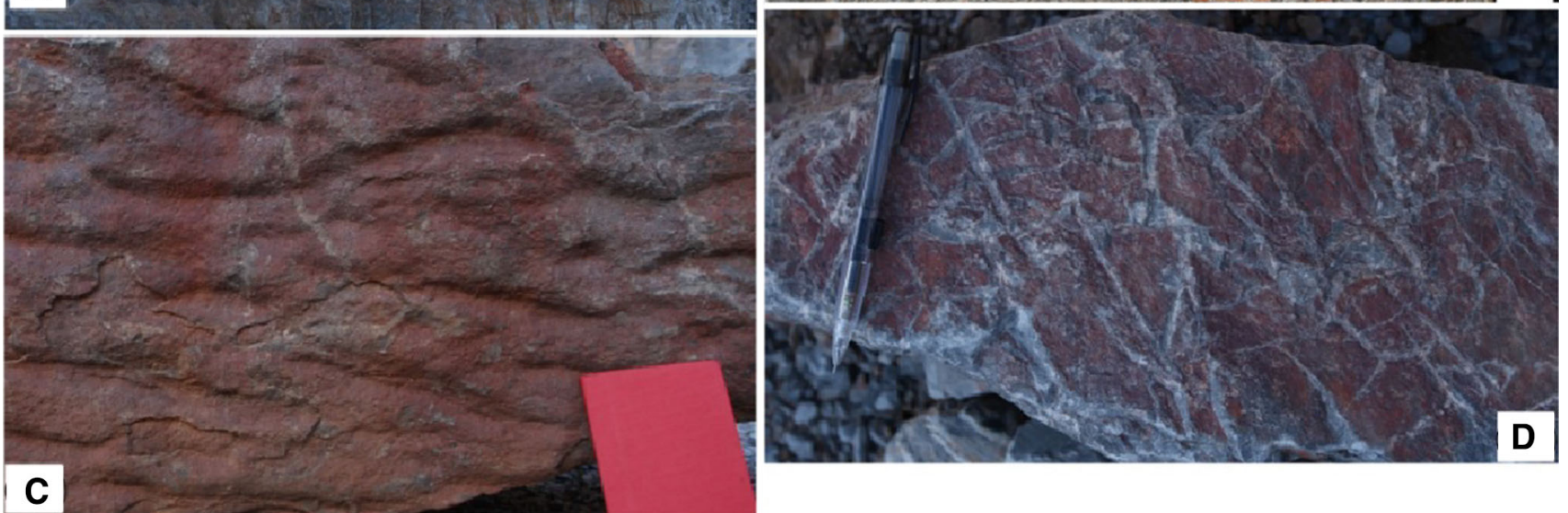

Fig. 5 a Stratiform stromatolite. b Stromatolitic dolostones containing a number of breccias. c Scour troughs on the surface of dolostone. d Mud cracks 
Fig. 6 a Photograph showing sedimentary architecture of the slope, the $a 1-b 1$ and $b 1-f 1$ represent the upper and lower part of the slope near the rimmed shelf, respectively. The rockfalls are encircled by white lines in $b 1-f 1$. b Details of the upper part of the slope, $a 2-b 2$ equals to $a 1-b 1$. The cleavages in mud are marked by ice blue dashed line. The white rectangle shows a deformation zone of the fault. c Faulted related folds in white rectangle, orange dashed lines represent the bedding surfaces.

d Dynamic recrystallization of calcites in the fold core.

e Rockfall, original strike is labelled by white line.

f Collapse breccia at the rear of $f 1$ in a. g Details of the mud cleavages in the left segment of b, the cleavages are denoted with black dashed lines
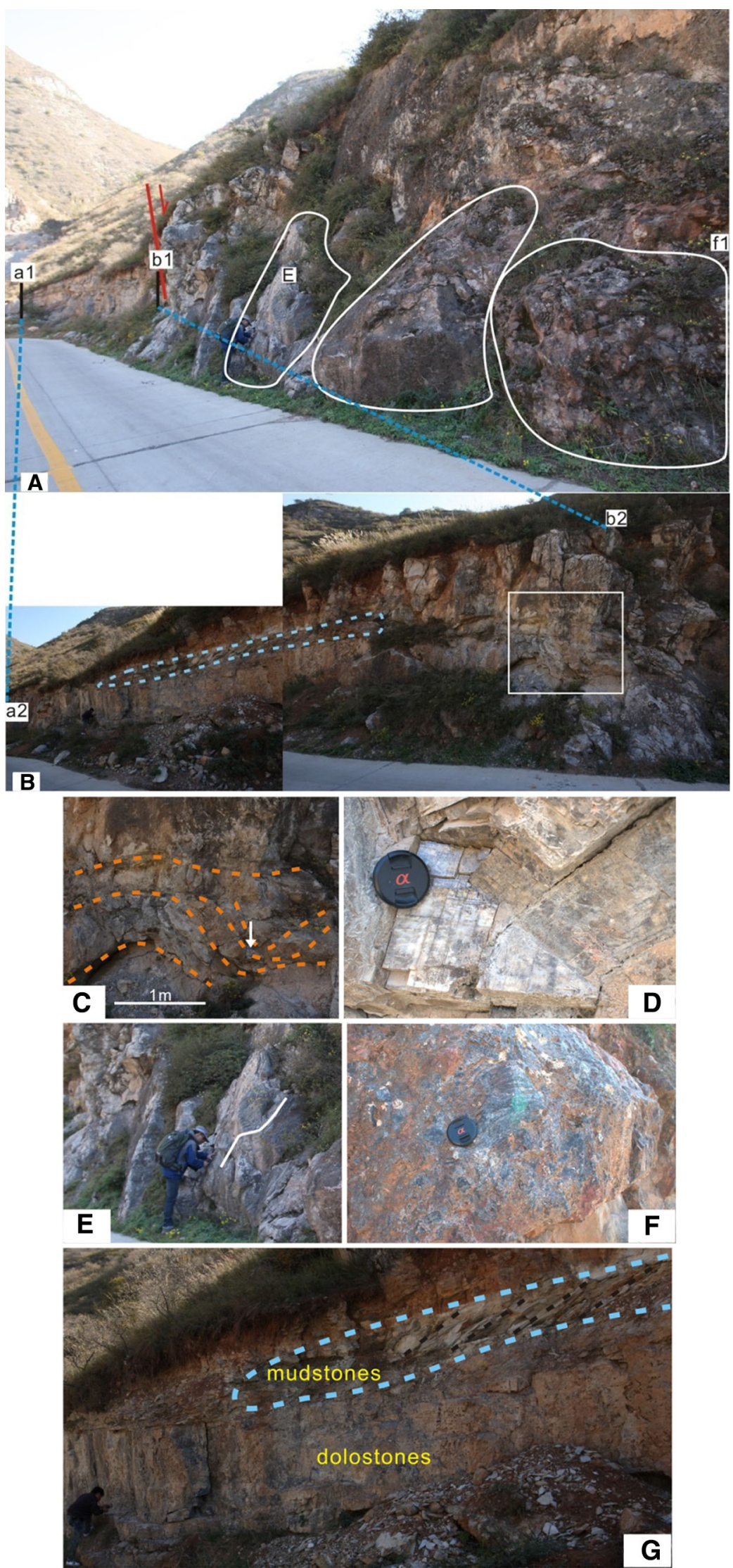
structures (a1-b1 of Fig. 6a, a2-b2 of Fig. 6b), while the lower part formed rockfalls (b1-f1 of Fig. 6a).

During normal fault development, fault propagation folds are formed to accommodate the variation of the displacement between the faulted beds and the unfaulted beds above the fault tips. They usually exhibit normal-drag geometry, with anticlines at the footwalls and synclines at the hanging walls. The amplitudes of the downwarping of the hanging wall and the upwarping of the footwall, as well as the subsidence and uplift at each wall respectively, increase with the fault dip and displacement (Erslev 1991; White and Crider 2006). As a consequence, the topographic variation is produced, which predominantly control the sedimentary environments. Hence, the propagation and evolution of the normal fault is the controlling factor for the carbonate rocks facies distribution.

During the early period of rifting, the intense tectonic movements produced high-angle normal fault, and drag anticline at its footwall. Its back limb extended into deep sea and formed the upper slope. As a result of subsidence of the back limb, the sedimentary environment was changed. A dolostone layer of 2-3 $\mathrm{m}$ in thickness and a mudstone layer of 1-2 $\mathrm{m}$ in thickness were deposited (Fig. $6 \mathrm{~g}$ ). Cleavages are found in mud, suggesting that slide took place along beds surfaces (Fig. 6b, g).

Breaks and minor folds are developed at the footwall close to the fault plane (Fig. 6b, c). A large number of dynamic recrystallization of calcites present in fold core (Fig. 6d). They indicate the fault had experienced intense activity.

Rockfalls and collapse breccias are seen in the lower slope (Fig. 6e, f). The size of rocks are several meters (encircled by white lines in b1-f1 of Fig. 6a). The original strike of rockfalls intersects strata with a high angle on the upper slope (Fig. 6e). The presence of siliceous dolomite, dolomite, algae dolomite and silicate in rockfalls suggests continental shelf provenance. The other parts of lower slope, far away from the fault, are covered by Cenozoic strata.

\section{Depositional model}

At the early stage of rifting, the syndepositional normal faults were active intensively. The footwall uplift and normal drag anticline were developed. The footwall's uplifting rate exceeded increasing of the sea level, and the rimmed shelves edge was elevated above the water, where rocks are weathered and easier to collapse (Hunt and Tucker 1995).

Seawardly, the depositional facies near rimmed platform margin are platform, platform edge and slope, corresponding to small tidal creek, mud cracks and scour troughs, slides and rockfalls respectively (Fig. 7).

\section{Sedimentary facies pattern of ramp type platform margin and fault activity}

\section{Platform edge facies}

Intraclastic dolostones usually present in the strata of ramptype carbonate platform edge shoals. As shown in the upper of stratigraphic column in point 4 (Fig. 2), the debris compositions are siliceous and dolomitic, with a size of 2-60 mm (Fig. 8a). Most of the rock fragments have long axis parallel to bedding surface, and the intraclastic dolostones incised into underlying bedded dolostones (Fig. 8a). The siliceous breccias are in radial arrangement at the top of this deposition unit (Fig. 8b). Intraclastic dolostones and bedded dolostones appear alternately, indicating the dynamically intense shallow-water environment.

In the middle of column (Fig. 3), cross beddings are well developed with an angle of $25^{\circ}-40^{\circ}$ with the sediment unit boundary (Fig. 8c). The hoary medium bedded oolitic dolomicrites exist in piont 3 (Fig. 8d), and the ooids type contains compound ooids and radial ooids, with a size between 0.2 and $1 \mathrm{~mm}$ (Fig. 8e). The radial ooids are included in compound ooids. The presence and characteristics of the cross-beddings and ooids suggest shoal microenvironment.

\section{Shelf facies}

Open marine shelves locate above the storm wave base in high-energy environment, and accumulate medium-thick bedded dolomite, thin-bedded siliceous dolomite and dolomite containing nodular cherts. As shown at point 3 (Fig. 3), tempestite sequence which includes three segments (erosion bottom, parallel bedding and hummocky lamination) emerges at the lower part (Fig. 9a). Compared with typical tempestite sequence, it lacks the graded bedding, interrupted laminae and mudstone in the study area (Aigner 1982). The tempestite's breccias are fan-shaped, and such kind of tempestites is regarded as in situ and deposition between fair-weather wave-base and storm wave-base, where presents strong hydrodynamic environment (Qiao 2001). Based on the presence of the tempestites and their adjacence to gravity flow deposits on outcrops, the tempestites here indicate the shelf environment.

As shown in the middle segment of the column at point 3 (Fig. 3), the nodular stromatolites are overlain by the bedded dolostones (Fig. 9b). The stromatolite suggests intertidal-subtidal depositional environment, with stronger hydrodynamics (Hoffman 1976). A dolomite lens presents close to the slope, with obvious sliding traces around it. Some fractures display at both the periphery and interior of the lens (Fig. 9c). The evidence of slide in local strata as a result of steep slope are the sedimentary structures, wavy 


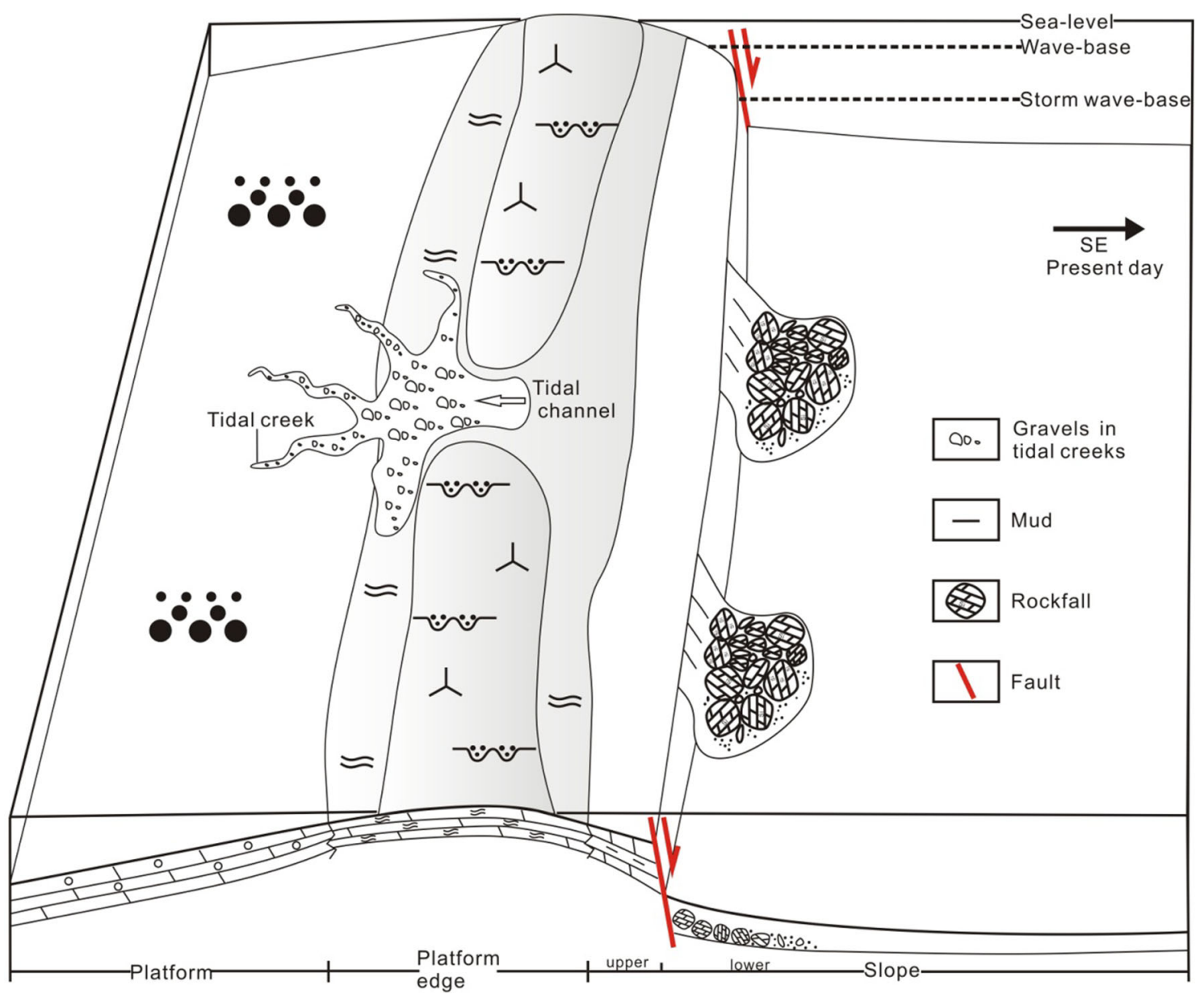

Fig. 7 Depositional model of rimmed platform margin in study area. Some symbols of lithology and sedimentary structure are seen in Fig. 3

laminations and loop bedding siliceous nodule, present in the middle-upper of the column (Fig. 9d, e). Though, the loop bedding nodules are thought to form by tensile stress along the layers as they are often arranged next to each other (Rodriguez-Pascua et al. 2000; Qiao and Li 2009), the nodules in the study area show remote distance from each other and lack tensile deformation. These features might be coherent with storm eddies (Ma et al. 2011). On the basis of all above, these sediments are settled in subtidal and high-energy environment.

\section{Slope facies and fault activity}

Carbonate debris flow deposit, often composed of carbonate clasts and micritic matrix, is a common type of sediment gravity flow deposits along the canyons or channels developed at the edge of the passive continental shelf (McHargue et al. 2011; Puga-Bernabéu et al. 2013). The gravity flow deposits are massively distributed and unsorted, and the deposits within the canyons and/or channels are lenticular (Scholle et al. 1983; Macauley and Hubbard 2013).
The observation at point 3 (Fig. 1) suggests the normal fault separates the open-marine shelf from the sediment gravity flow deposits on the slope (Fig. 10b). The formations in footwall are undeformed, suggesting that the fault activity has attenuated impacts on the footwall. The hangingwall is consisted of hoary massive debris flow sediments with matrix-supported fabric. The debris components are long-strip or ellipsoidal dolomites and silicalites in size of $1-100 \mathrm{~mm}$, which show disordered arrangement (Fig. 10c). Lenticular channels or canyons are overlapping each other, and are enclosed by the gravity flow deposits (Fig. 10a). The thicknesses of the lenses are commonly $0.3-1.5 \mathrm{~m}$ (Fig. 10d). In the matrix, the large particles of debris are floating in the size of $1-100 \mathrm{~mm}$ (Fig. 10e), comprised of the dolomitic and siliceous gravels (Fig. 10f).

\section{Depositional model}

The syn-depositional normal faults became inactive during the late stage of the rifting, and facilitated a ramp-type carbonate platform. From landward to seaward, the 
Fig. 8 a Intraclastic dolostone. b The larger scale map of yellow rectangle in a. c Cross beddings in dolostones highlighted by dashed yellow lines. d Oolitic dolostone. e Photomicrograph of $\mathbf{d}$, including compound ooids and radial ooids

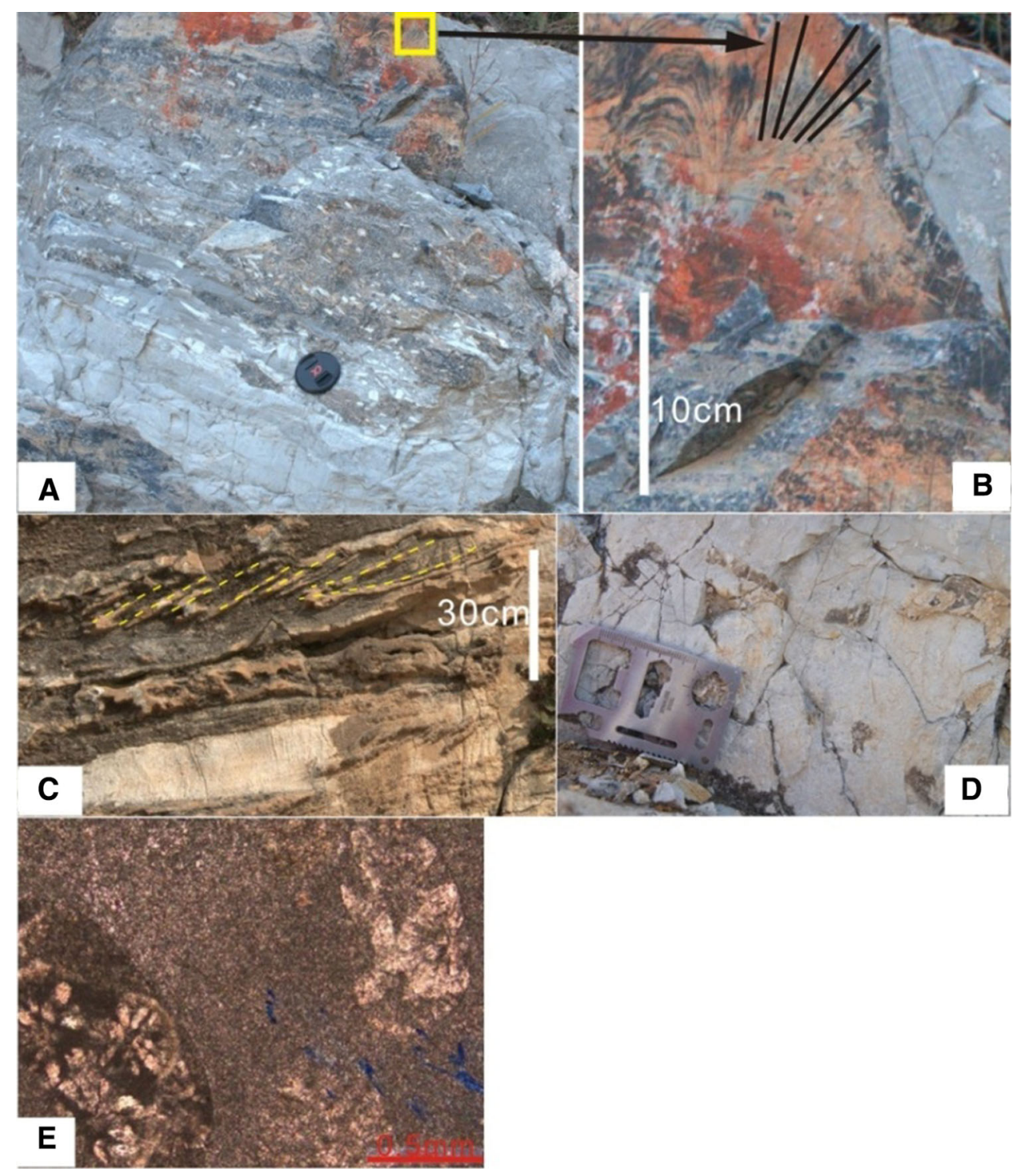

depositional facies at the ramp-type platform margin are platform edge, shelf and slope, correspondingly with main characteristics of: (1) intraclastic dolostones, oolitic dolostones; (2) tempestites, nodular stromatolities, dolostones with wavy laminations and loop bedding; (3) debris flow sediments, respectively (Fig. 11).

\section{Discussions}

\section{The impacts of tectonism on carbonate platform}

Sea-level fluctuations can influence the type of carbonate platform and characteristics of gravity flow deposits (Read 1985; Reijmer et al. 2012; Phelps et al. 2014). Many studies have been focused on the sea-level changes of the Jixian Period of Mesoproterozoic at the eastern North
China plate, but few studies try to address the problem from the southern margin of the North China plate. According to presence and features of stromatolites, the Jixian Group, are contemporary with the Wumishan Formation in the east (Yan et al. 1989; Di 2003). The deposition of the Wumishan Formation records a sea level increase (Gao et al. 1996; Mei et al. 1999, 2000), which was caused by tectonism rather than climate change (Gao et al. 1996). The tectonics and eustatic events are likely to match in the study area.

In Mesoproterozoic Jixian Period, the southwest of Ordos block is modified by the Longshan-Kuanping rift and the Haiyuan rift, while the southeast is only effected by the former (Huo and Zheng 1988; Wu et al. 2002; Di 2003; Li et al. 2006; Dong et al. 2014). The tectonic subsidence is more intense and the Jixian Group is thicker in the southwest (Di 2003). In this study, the rimmed and ramp type

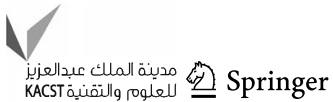


platforms presents, and sediment gravity flow deposits are well developed on the slope in the southwest. On the contrary, the ramp platforms dominated in the southeast, and the related sediment gravity flow deposits are poorly developed ( $\mathrm{Lu}$ et al. 2013). All of above suggests that tectonics plays an important role in defining the type of carbonate platform in late Mesoproterozoic.

The carbonate platform types are divided mainly based on the paleotopography, composition and distribution of sediments, tectonic settings, and sealing of the platform
Fig. 10 a Channel or canyon deposits on slope circled by black line. b The fault between open-marine shelf deposits and debris flow deposits on slope. c Boundary of the debris flow (the left) and the channel deposits (the right), location " $b$ " refer to a. d Channel lenses marked by yellow dashed lines, location " $a$ " refer to a. e Dolomite and silicalite debris floating in lenses. f Photomicrograph of $\mathbf{e}$

margin to the seawater inside (Wilson 1975; Read 1985; Mei et al. 1997; Bosence 2005; Gu et al. 2009). Concretely, tectonic movements primarily manipulate
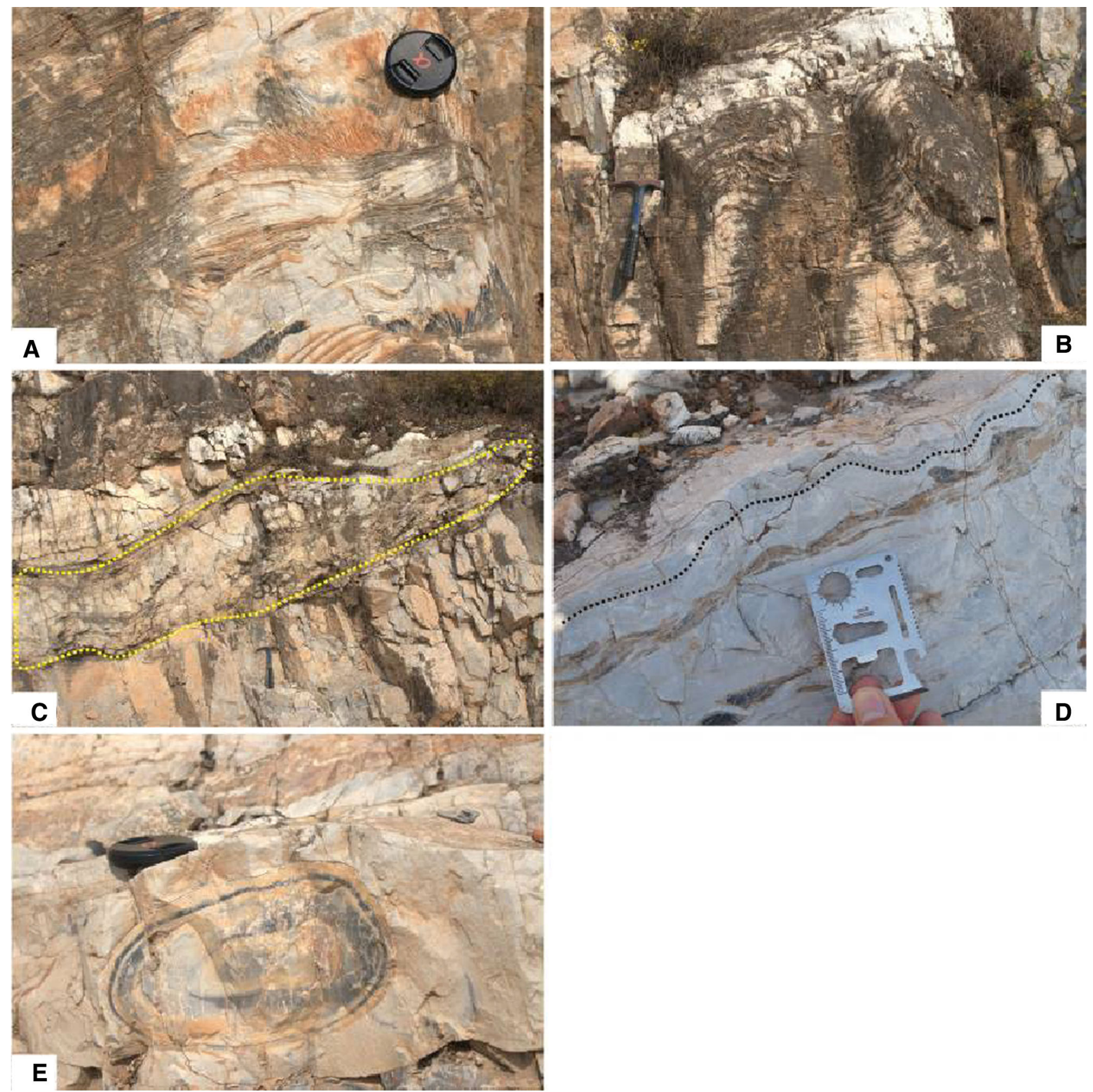

Fig. 9 a Tempestites. b Nodular stromatolites. c Sliding deformations highlighted by dashed yellow line. d Wavy laminations. e Loop bedding

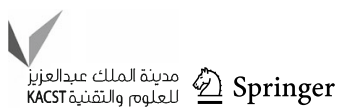



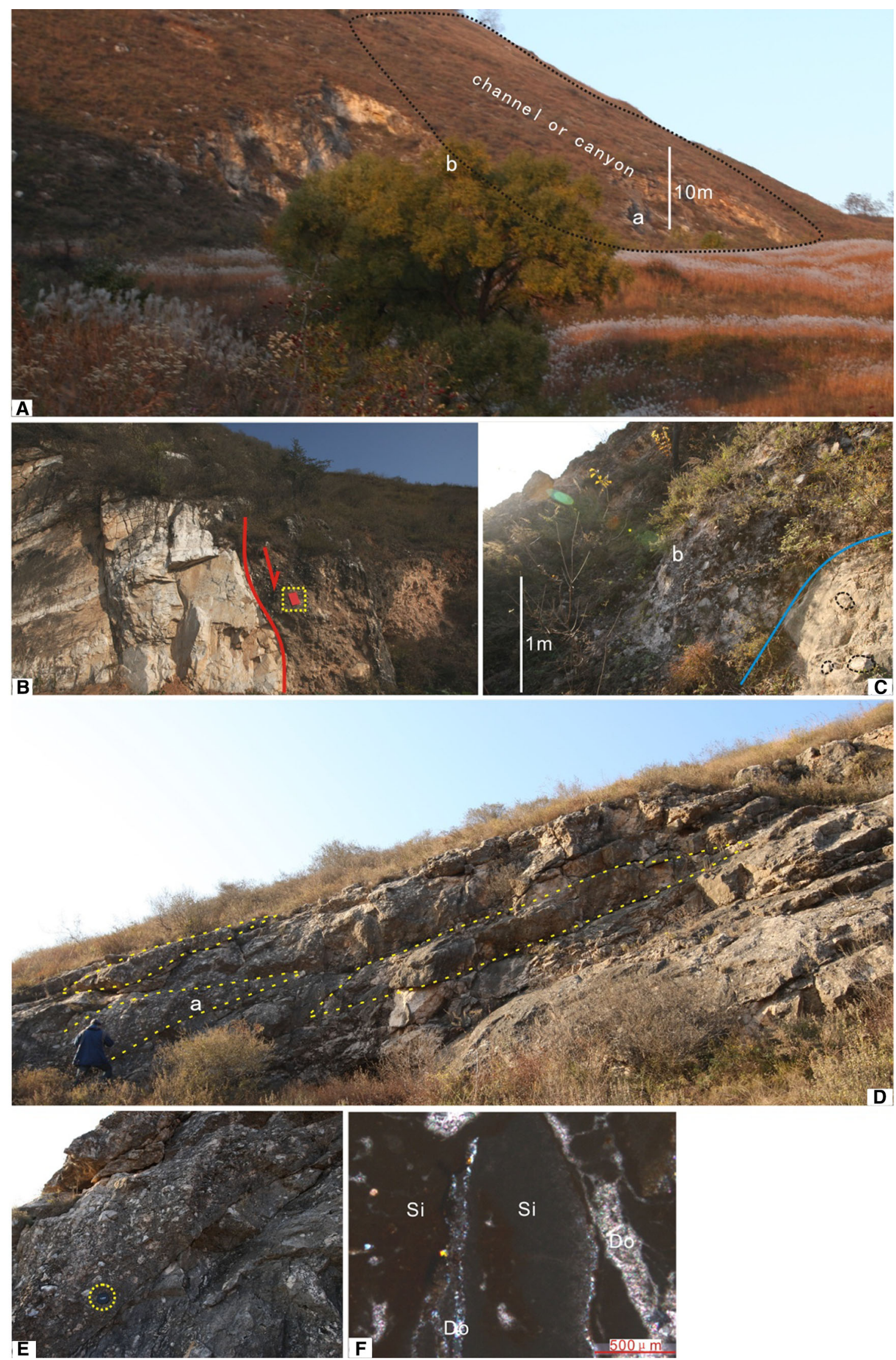


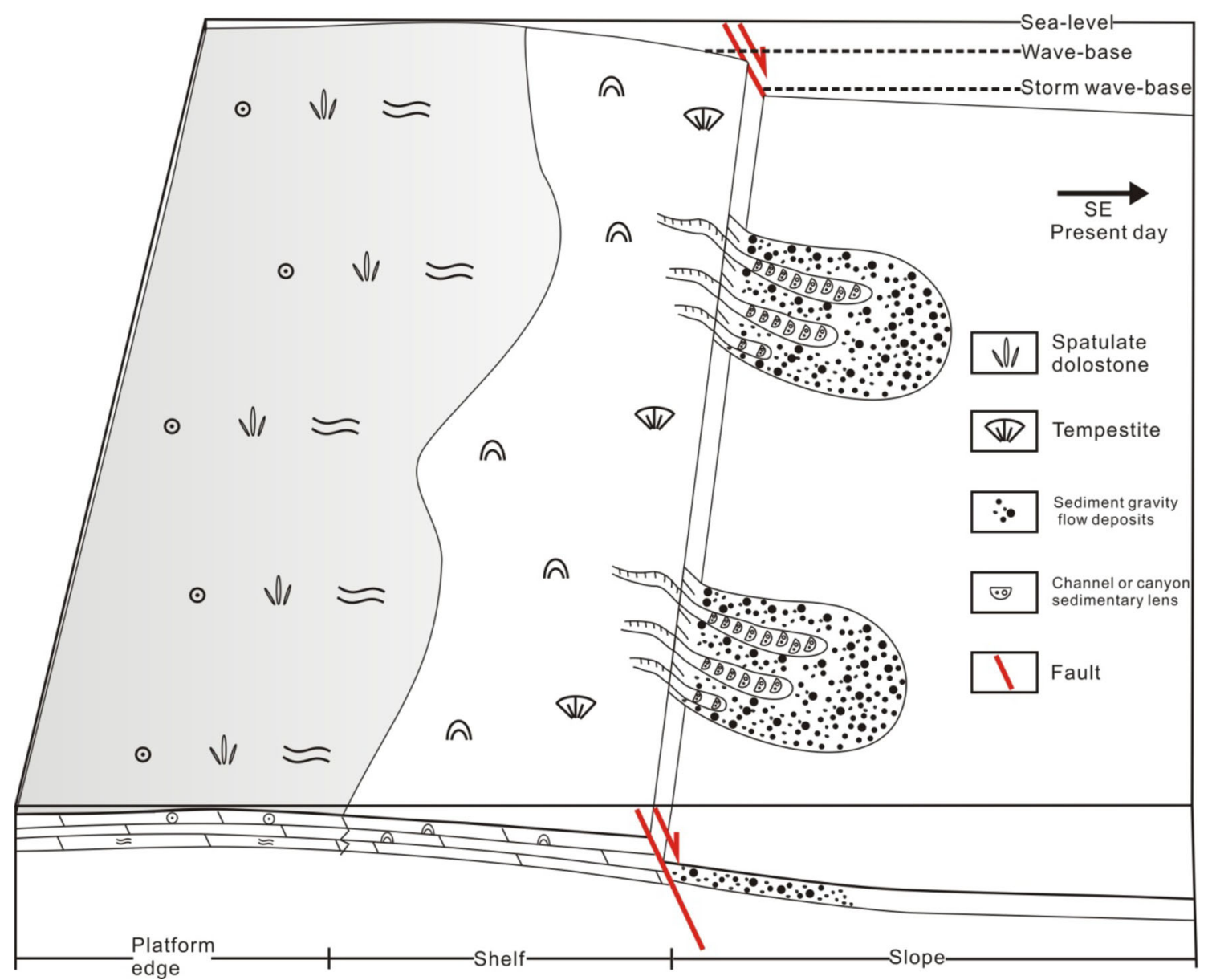

Fig. 11 Depositional model of ramp-type platform margin in study area. Symbols of lithology and sedimentary structure are seen in Fig. 3

paleotopography, which determines the composition and distribution of sediments, thus the platform's types (Vail et al. 1991; Mei et al. 1997; Gómez and Fernández-López 2006).

Faults, as a major form of rifting movements, control the architecture and depositional sequences of fault-block carbonate platform (Bosence et al. 1998; Preto et al. 2011), and impact depositional environment and facies distributions of hangingwall and footwall (Wilson 1999). The platform boundary fault affects the type of slope sediments and platform geomorphology (Yilmaz 2006; Lü et al. 2013; Quiquerez et al. 2013). Therefore, syn-depositional faults could be a key factor when judging the type of the carbonate platform.

\section{The effect of tectonism on source beds}

Tectonism may control the sedimentary environment of source beds as well as its distribution. At the early stage of rifting, the activity of faulting at the margin of platform may lead to the exposure of the shelf edge and the formation of islands, which limited the water exchange on the platform and was conducive to the preservation of organic matter. At the late stage of rifting, the weakened activity of faulting made it easy to form open marine shelves. Meanwhile, the presence of tempestite suggests water upwelling from deep ocean may have occurred. This water movement can bring rich nutrients up to facilitate the productivity of organic matter in euphotic zone. Theoretically, an anoxic environment created by degration of dead organic matter benefits the generation and preservation of organic matter itself in shelf. Although, the observation line is confined by landform, the conclusion that the link between distribution of source beds with tectonism still needs to be further proved.

\section{Conclusions}

This study presents a detailed description of the impacts of fault activity on the sedimentary facies of carbonate platform margin and the types of slopes. At the early stage, the 
syn-depositional normal faults acted intensely, causing the uplift of its footwall and the formation of high steep rimmed platform. The local depositional environments were affected by the fault propagation folds. The related depositional environments were platform, platform edge and slope successively. At the late stage, the fault activity weakened, and the platform was transformed to a ramptype with the gradient decrease of the slopes. The depositional environments of this period are platform edge, shelf and slope respectively.

In conclusion, the study area was a transition zone between the edge of the continental shelf and the slopes during Mesoproterozoic Jixian period. And tectonic movements induced the conversion of the carbonate platform from rimmed type to ramp type. Also, tectonism controls the depositional environment and distribution of source beds.

Acknowledgments The authors are very grateful to Ph.D. Tariq Alkhalifah and Reviewers for comments and suggestions. This project was supported by China National Science and Technology Major Project 2016ZX05008-004.

Open Access This article is distributed under the terms of the Creative Commons Attribution 4.0 International License (http:// creativecommons.org/licenses/by/4.0/), which permits unrestricted use, distribution, and reproduction in any medium, provided you give appropriate credit to the original author(s) and the source, provide a link to the Creative Commons license, and indicate if changes were made.

\section{References}

Aigner T (1982) Calcareous tempestites: storm-dominanted stratification in Upper Muschelkalk limestones (Middle Trias, SWGermany). In: Einsele G, Seilacher A (eds) Cyclic and event stratification. Springer, Berlin, pp 180-198

Bai J (1993) Precambrian crustal evolution in China. Geological Publishing House, Beijing, pp 157-165

Bosence D (2005) A genetic classification of carbonate platforms based on their basinal and tectonic settings in the Cenozoic. Sed Geol 175:49-72

Bosence D, Cross N, Hardy S (1998) Architecture and depositional sequences of Tertiary fault-block carbonate platforms; an analysis from outcrop (Miocene, Gulf of Suez) and computer modeling. Mar Pet Geol 15:203-221

Deng K, Zhang S, Zhou L, Liu Z, Li W (2009) Depositional environments and hydrocarbon potential of Jixian System in southwestern margin of the Ordos basin. Nat Gas Ind 29(3):21-24

Di L (2003) Research on basal revolution and sediment cover in Ordos basin. Northwest University, Shaanxi, pp 26-60

Dong Y, Zhao Y, Liu X, Zhang X, He D, Wei L, Zhang F, Sun S, Zhang H, Zhang G (2014) Neoproterozoic amalgamation of the Northern Qinling terrain to the North China Craton: constraints from geochronology and geochemistry of the Kuanping ophiolite. Precambr Res 255:77-95
Erslev EA (1991) Trishear fault-propagation folding. Geology 19(6):617-620

Gao Z, Zhang Y, Wang C, Tian S, Peng Y, Liu Y, Dong D, He H, Lei B, Chen M, Yang L (1996) Primary investigation on Meso-to Neoproterozoic stratigraphic sequence in Jixian, Tianjin. Reg Geol Chin 1:64-74

Gao L, Zhang C, Yin C, Shi X, Wang Z, Liu Y, Liu P, Tang F, Song B (2008) SHRIMP Zircon Ages: basis for Refining the chronostratigraphic classification of the Meso-and Neoproterozoic strata in North China old land. Acta Geosci Sin 29(3):366-376

GBSP (Geology Bureau of the Shaanxi Province) (1966) Regional geology of Shaanxi Province. Geological Publishing House, Beijing, p 29

Gómez JJ, Fernández-López SR (2006) The Iberian Middle Jurassic carbonate-platform system: synthesis of the palaeogeographic elements of its eastern margin (Spain). Palaeogeogr Palaeclimatol Palaeocl 236(3-4):190-205

Gu J, Ma F, Ji L (2009) Types, characteristics and main controlling factors of carbonate platform. J Palaeogeogr 11(1):21-27

Hoffman P (1976) Environmental diversity of Middle Precambrian stromatolites. In: Walter MR (ed) Stromatolites. Elsevier, Amsterdam, pp 599-611

Hunt D, Tucker ME (1995) Stranded parasequences and the forced regressive wedge systems tract: deposition during base-level fall-reply. Sed Geol 95(1-2):147-160

Huo F, Zheng Z (1988) The age and correlation of the original Haiyuan Group in the Haiyuan area, Ningxia. Geol Rev 34(1):1-9

Li T, Zhang X, Wang C, Wang R (2006) Reconstruction of protoliths of metamorphic rocks and tectonic setting of the Haiyuan Group in the Haiyuan in the eastern segment of the North Qilian Mountains, China. Geol Bull Chin 25(1-2):194-203

Li R, Liang J, Weng K (2011) Paleo-oil reservoir of Jixian System in Southwestern Ordos basin. Pet Explor Dev 38(2):173-186

Lu M, Chen Y, Wu G, Peng W, Wang L (2013) Mesoproterozoic sedimentary facies and seismites sequence division in the southern margin of Ordos basin. J Northeast Pet Univ 37(2):37-45

Lü C, Wu S, Yao Y, Fulthorpe CS (2013) Development and controlling factors of Miocene carbonate platform in the Nam Con Son Basin, southwestern South China Sea. Mar Pet Geol 45:55-68

Ma R, Zhang L, Du Y, Wang X (2011) Sedimentary characteristics and its geological implications of Cambrian tempestite in Northern Henan Province. Geol Sci Technol Inf 30(4):15-20

Macauley RV, Hubbard SM (2013) Slope channel sedimentary processes and stratigraphic stacking, Cretaceous Tres Pasos Formation slope system, Chilean Patagonia. Mar Pet Geol 41:146-162

McHargue T, Pyrcz MJ, Sullivan MD, Clark JD, Fildani A, Romans BW, Covault JA, Levy M, Posamentier HW, Drinkwater NJ (2011) Architecture of turbidite channel systems on the continental slope: patterns and predictions. Mar Pet Geol 28(3):728-743

Mei M, Ma Y, Zhou P (1997) An introduction to the carbonate sedimentology. Seismological Press, Beijing, pp 56-65

Mei M, Du B, Zhou H, Luo Z (1999) A preliminary study of the cyclic sequences of composite sea-level changes in the Mesoproterozoic Wumishan Formation in Jixian, Tianjin. Sed Facies Palaeogeogr 19(5):12-22

Mei M, Zhou H, Du B, Luo Z (2000) Meso- and Neoproterozoic sedimentary sequences in Jixian, Tianjin, northern China: division of the first-order sequences of the Cambrain strata (1800-600 Ma) and their correlation with the Phanerozoic strata. Sed Geol Tethyan Geol 20(4):47-59 
Peng P (2010) Reconstruction and interpretation of giant mafic dyke swarms: a case study of $1.78 \mathrm{Ga}$ magmatism in the North China Craton. In: Kusky T, Zhai M, Xiao W (eds) The evolving continents: understanding processes of continental growth, vol 338. Geological Society of London Special Publication, London, pp $163-178$

Phelps RM, Kerans C, Loucks RG, Gama R, Jeremiah J, Hull D (2014) Oceanographic and eustatic control of carbonate platform evolution and sequence stratigraphy on the Cretaceous (Valanginian-Campanian) passive margin, northern Gulf of Mexico. Sedimentology 61:461-496

Preto N, Franceschi M, Gattolin G, Massironi M, Riva A, Gramigna P, Bertoldi P, Bertoldi L, Nardon S (2011) The Latemar: a Middle Triassic polygonal fault-block platform controlled by synsedimentary tectonics. Sed Geol 234(1-4):1-18

Puga-Bernabéu A, Webster JM, Beaman RJ, Guilbaud V (2013) Variation in canyon morphology on the Great Barrier Reef margin, north-eastern Australia: the influence of slope and barrier reefs. Geomorphology 191:35-50

Qiao X (2001) Neoproterozoic Erathem in the Tanlu fault zone: Cataclysm, Sequences, Organisms. Geological Publishing House, Beijing, pp 12-24

Qiao X, Li H (2009) Effect of earthquake and ancient earthquake on sediments. J Palaeogeogr 11(6):593-610

Quiquerez A, Sarih S, Allemand P (2013) Fault rate controls on carbonate gravity-flow deposits of the Liassic of Central High Atlas (Morocco). Mar Pet Geol 43:349-369

Read JF (1985) Carbonate platform facies models. AAPG Bull 69:1-21

Reijmer JJG, Palmieri P, Groen R (2012) Compositional variations in calciturbidites and calcidebrites in response to sea-level fluctuations (Exuma Sound, Bahamas). Facies 58(4):493-507

Rodrıguez-Pascua MA, Calvo JP, Vicete GD, Gómez-Gras D (2000) Soft-sediment deformation structure interpreted as seismites in lacustrine sediments of the Prebetic Zone, SE Spain, and their potential use as indicators of earthquake magnitudes during the Late Miocene. Sed Geol 135:117-135

Scholle PA, Bebout DG, Moore CH (1983) Carbonate depositional environments. AAPG Mem 33:175-615

Sun S, Zhang G, Chen Z (1985) Geological evolution of the Precambrian Southern Northern China Block. Metallugy Industry Press, Beijing, pp 90-149
Tang X, Xu L, Lu J (1993) Crystalline basement and deep geological research on Shan-Gan-Ning basin and its peripheral regions. Research institute of exploration and development of Changqing oil field, Xi'an, pp 105-107

Vail PR, Audemard F, Bowman SA (1991) The stratigraphic signature of tectonics, eustasy and sedimentation-an overview. In: Einsele G, Ricken W, Seilacher A (eds) Cycles and events in stratigraphy. Springer, Berlin, pp 617-659

Varnes DJ (1978) Slope movement types and processes. Landslide analysis and control. In: Transportation Research Board, Special Report No. 176. National Academy of Sciences, Washington, pp 11-33

White IR, Crider JG (2006) Extensional fault-propagation folds: mechanical models and observations from the Modoc Plateau, northeastern California. J Struct Geol 28(7):1352-1370

Wilson JL (1975) Carbonate facies in geologic history. Springer, Berlin, pp 20-55

Wilson MEJ (1999) Prerift and synrift sedimentation during early fault segmentation of a Tertiary carbonate platform, Indonesia. Mar Pet Geol 16:825-848

Wu T (2002) Late Precambrian (Meso-to Neoproterozoic) lithostratigraphic units in North China and their multiple division and correlation. Geol Chin 29(2):147-154

Wu M, Guo Y, Liu C, Zuo G (2002) Study on Sm-Nd isotope chronology of the Longshan Group, Eastern Gansu Province, and its tectonic significance. Geol Rev 48(Supp):59-63

Yan Z, Zhang H, Huang Y (1989) Regional geology of Shaanxi Province. Geological Publishing House, Beijing, pp 13-38

Yilmaz C (2006) Platform-slope transition during rifting: the midCretaceous succession of the Amasya Region (Northern Anatolia), Turkey. J Asian Earth Sci 27(2):194-206

Zhang K (1983) Recommend on faulted depression in Helanshan \Petroleum geology essays about the western margin of Ordos basin. Inner People's Publishing House, Huhehaote, pp 29-40

Zhang G, Zhu J, Wang Y, Wang H (1984) Study on modern tidal creek sedimentary in Qionggang, Northern Jiangsu. Acta Oceanol Sin 6(2):223-234

Zhao T, Zhou M (2009) Geochemical constraints on the tectonic setting of Paleoproterozoic A-type granites in the southern margin of the North China Craton. J Asian Earth Sci 36(2-3):183-195 